\title{
VIBRATION ANALYSIS OF A THIN RING INTERACTING WITH THE ANNULAR PLATE TREATED AS AN ELASTIC FOUNDATION
}

\begin{abstract}
In this paper the free in-plane flexural vibration of a thin ring with elastic foundation of a Winkler type is analysed on the basis of the analytical and numerical methods. Mathematical model of the three-parameter elastic foundation is proposed. The separation of variables method is used to obtain the general solution of the considered system free vibration. Then the eigenvalue problem is solved by using the finite element method. Natural frequencies and normal modes of the system vibration are determined. The achieved results of calculation are discussed and verified by experimental data. FE model is formulated by using ANSYS software. It is important to note that the problems discussed in the paper bring practical advice for engineers dealing with dynamics of circular ring systems like aviation gears and railway wheels, respectively.
\end{abstract}

Keywords: in-plane flexural vibration, ring with foundation, three-parameter elastic foundation, circular systems

\section{Introduction}

The vibration theory of thin rings with wheel-plate as an elastic foundation finds application in several fields of engineering including the railway and aviation industries, and others $[1,2,6]$. The fundamental vibration theory of circular rings is presented in monograph [5]. The theory of thin circular rings is employed in paper [6] for a vibration analysis of a ring gear. Vibration of rotating rings with foundation are studied in paper [1]. The introductory investigation related to the systems of the rings with wheel-plate as the elastic foundation are conducted in articles [3,4]. In paper [2] the analytical model of foundation which consists of a special three-parameter Winkler elastic foundation is proposed. In the present paper the free in-plane flexural vibration of a circular ring with

\footnotetext{
${ }^{1}$ Autor do korespondencji/corresponding author: Stanisław Noga, Rzeszow University of Technology, al. Powstańców Warszawy 12, 35-959 Rzeszów, tel.: 178651639, e-mail: noga@prz.edu.pl
} 
wheel-plate as a special three-parameter elastic foundation is studied using the classical thin ring theory, and the finite element (FE) formulation. The procedure of determining the substitute mass density of a system consisting of a ring with massless elastic foundation is presented. The achieved solutions are discussed and compared with experimental data. An experimental test is conducted by applying an object with arbitrary chosen geometry.

\section{Theoretical formulation}

Mechanical model of the system under consideration consists of a plane circular thin ring with wheel-plate as a special three-parameter, elastic foundation. It is assumed that the ring is perfectly elastic and that the centerline of the ring has radius $R$ and an element of the ring, designed by angle $\theta$, displaces in the radial and circumferential direction, respectively (see Fig. 1). Moreover, it is assumed that the ring has homogeneous, rectangular cross-sectional area. The small displacements in these directions are denoted $u(\theta, t)$ and $w(\theta, t)$, respectively, and $t$ is time. Similarly as in paper [2], the foundation is formulated by the special three-parameter Winkler model. The coefficients $k_{f}, k_{p}$ and $k_{S}$ represent the radial and tangential stiffness per length unit, and the ring cross-section angle rotation stiffness modulus, respectively.

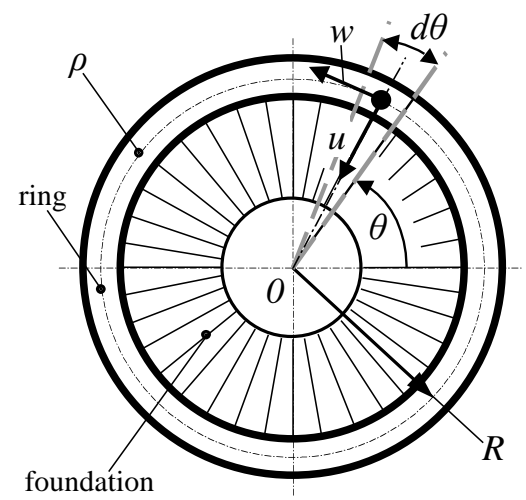

Fig. 1. Vibrating system under study

Rys. 1. Model układu drgającego

According to the vibrating thing rings classical theory [2,5], the partial differential equations of motion for the free in-plane flexural vibration can be combined into an one equation in terms of radial deflection $u(\theta, t)$ as 


$$
\begin{array}{r}
\frac{E I_{1}}{R^{3}}\left(\frac{\partial^{6} u}{\partial \theta^{6}}+2 \frac{\partial^{4} u}{\partial \theta^{4}}+\frac{\partial^{2} u}{\partial \theta^{2}}\right)-\frac{k_{S}}{R}\left(\frac{\partial^{4} u}{\partial \theta^{4}}+2 \frac{\partial^{2} u}{\partial \theta^{2}}+u\right)+ \\
\left(k_{f} \frac{\partial^{2} u}{\partial \theta^{2}}-k_{p} u\right) R+\rho A R \frac{\partial^{2}}{\partial t^{2}}\left(\frac{\partial^{2} u}{\partial \theta^{2}}-u\right)=0
\end{array}
$$

where: $E \quad-$ Young's modulus,

$I_{1}$ - the rim cross section area moment of inertia,

$\rho$ - the mass density,

$A$ - the cross section area.

The general solution of equation (1) is assumed in the form

$$
u(\theta, t)=U(\theta) \mathrm{e}^{\mathrm{i} \omega t}
$$

where: $\omega$

$$
\mathrm{i}=\sqrt{-1}
$$

- the natural frequency,

$$
\text { - the imaginary unit. }
$$

After substitution (2) into equation (1), it becomes

$$
\begin{array}{r}
\frac{\mathrm{d}^{6} U}{\mathrm{~d} \theta^{6}}+\left(2-h_{1}\right) \frac{\mathrm{d}^{4} U}{\mathrm{~d} \theta^{4}}+\left(1-2 h_{1}+a_{1}\right) \frac{\mathrm{d}^{2} U}{\mathrm{~d} \theta^{2}}- \\
\left(c_{1}+h_{1}\right) U-\omega^{2} b_{1}\left(\frac{\mathrm{d}^{2} U}{\mathrm{~d} \theta^{2}}-U\right)=0
\end{array}
$$

where:

$$
a_{1}=\frac{k_{f} R^{4}}{E I_{1}}, b_{1}=\frac{\rho A R^{4}}{E I_{1}}, c_{1}=\frac{k_{p} R^{4}}{E I_{1}}, h_{1}=\frac{k_{S} R^{2}}{E I_{1}} .
$$

The solution of equation (3) is assumed as

$$
U(\theta)=\sum_{j=1}^{3} D_{j n} \sin \left(n \theta+\varphi_{j n}\right), n=2,3, \ldots
$$

where: $D_{j n}, \varphi_{j n} \quad-$ constants.

When equation (5) is substituted into equation (3), it yields the natural frequencies of vibration as 


$$
\omega_{n}^{2}=\frac{n^{6}-\left(2-h_{1}\right) n^{4}+\left(1-2 h_{1}+a_{1}\right) n^{2}+\left(c_{1}+h_{1}\right)}{b_{1}\left(n^{2}+1\right)}, n=2,3, \ldots
$$

As denoted in the previously presented equations, $n$ must be an integer with a value greater than 1 . For the case when $n$ is equal 1 only the pure rigid body oscillation without any alteration of ring shape exists.

\section{The finite element representation}

In this section the discrete model of the system under study is formulated using finite element method (ANSYS program). To find the eigenpairs (eigenvalue, eigenvector) connected with the natural frequencies and normal modes of the ring system, the block Lanczos method is employed [5]. The principal problem of this section is the elaboration of the FE model of the system with proper value of the ring substitute mass density $\rho_{z}$ and massless elastic foundation, respectively. The analysed object has the geometry as it is displayed in Fig. 2. The proposed FE model is realized as follows. The ring part is modeled as the solid body and the foundation part is prepared as the massless solid body.

a)

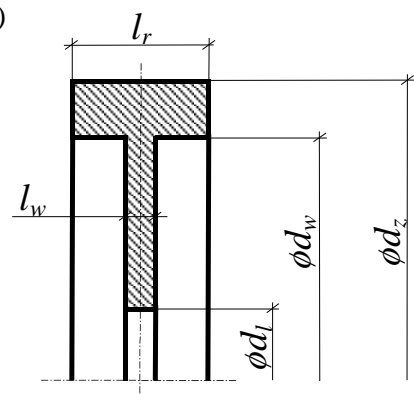

b)

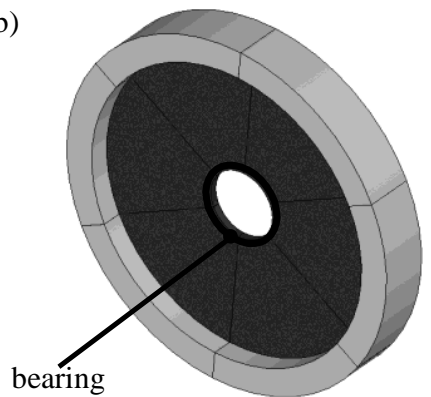

Fig. 2. (a) geometrical dimensions, (b) model of the system

Rys. 2. (a) wymiary geometryczne, (b) model układu

The ten node tetrahedral element (solid187) with three degrees of freedom in each node is utilized to solve the considered problem. The proper value of the substitute mass density $\rho_{z}$ of the ring system is selected during simulation to minimise the so-called frequency error defined by [2]

$$
\varepsilon_{n}=\left(\omega_{n}^{f}-\omega_{n}^{c}\right) / \omega_{n}^{c} \cdot 100 \%
$$

where: $\omega_{n}^{f}-$ the natural frequency of the model,

$\omega_{n}^{c}$ - the natural frequency of the object.

The elaborated FE model includes 54858 solid elements. 


\section{Numerical analysis}

Numerical solutions for free vibration analysis of the circular ring with wheel-plate, models suggested earlier, are obtained. For all results presented here, the first seven natural frequencies and corresponding normal modes are discussed.

Table 1. Parameters characterizing the system of ring with foundation

Tabela 1. Parametry techniczne rozważanego układu pierścieniowego

\begin{tabular}{|c|c|c|c|c|c|c|c|c|c|}
\hline $\begin{array}{c}\boldsymbol{d}_{z} \\
{[\mathrm{~m}]}\end{array}$ & $\begin{array}{c}\boldsymbol{d}_{\boldsymbol{w}} \\
{[\mathrm{m}]}\end{array}$ & $\begin{array}{c}\boldsymbol{h} \\
{[\mathrm{m}]}\end{array}$ & $\begin{array}{c}\rho \\
{\left[\mathrm{kg} / \mathrm{m}^{3}\right]}\end{array}$ & $\begin{array}{l}\mathbf{R} \\
{[\mathrm{m}]} \\
\end{array}$ & $\begin{array}{c}\boldsymbol{d}_{\boldsymbol{I}} \\
{[\mathrm{m}]}\end{array}$ & $\begin{array}{c}\boldsymbol{l}_{\boldsymbol{r}} \\
{[\mathrm{m}]}\end{array}$ & $\begin{array}{c}\boldsymbol{l}_{\boldsymbol{w}} \\
{[\mathrm{m}]}\end{array}$ & \begin{tabular}{|l} 
\\
{$[\mathrm{Pa}]$} \\
\end{tabular} & $v$ \\
\hline 0.179 & 0.171 & 0.004 & $7.85 \cdot 10^{3}$ & 0.0875 & 0.02 & 0.008 & 0.002 & $2.1 \cdot 10^{11}$ & 0.28 \\
\hline
\end{tabular}

Table 1 shows the parameters characterizing the considered system. In this Table, $h$ is the depth of the ring, $v$ is the Poisson ratio and the rest of geometrical dimensions are defined as displayed in Fig. 2. Firstly, the computations are conducted to determine the ring substitute mass density $\rho_{z}$ of the FE model related to the corresponding object. Satisfactory results are achieved for the value of $\rho_{z}=1.5 \cdot 10^{4}\left[\mathrm{~kg} / \mathrm{m}^{3}\right]$. The same value of $\rho_{z}$ is included in the analytical solution. Then the proper values of stiffness modulus $k_{f}, k_{p}$ and $k_{S}$ in the analytical model are evaluated during numerical simulation. The results of calculations of the natural frequencies are displayed in Table 2.

Table 2. Results of calculations related to the system under study

Tabela 2. Wyniki obliczeń odnoszących się do badanego układu

\begin{tabular}{|c|c|c|c|c|c|c|c|c|c|}
\hline $\begin{array}{c}\boldsymbol{n} \\
\boldsymbol{k}_{\boldsymbol{f}} \\
{\left[\mathrm{N} / \mathrm{m}^{2}\right]}\end{array}$ & $\begin{array}{c}\boldsymbol{k}_{\boldsymbol{p}} \\
{\left[\mathrm{N} / \mathrm{m}^{2}\right]}\end{array}$ & $\begin{array}{c}\boldsymbol{k}_{\boldsymbol{S}} \\
{[\mathrm{N} / \mathrm{m}]}\end{array}$ & 2 & 3 & 4 & 5 & 6 & 7 & 8 \\
\hline \multicolumn{10}{|c|}{ natural frequencies of the considered model $\omega_{n}[\mathrm{~Hz}]$ (analytical solution) } \\
\hline $2.44 \cdot 10^{9}$ & $6 \cdot 10^{8}$ & $3.5 \cdot 10^{6}$ & 12362 & 16550 & 21072 & 25767 & 30569 & 35450 & 40396 \\
\hline \multicolumn{10}{|c|}{ natural frequencies of the considered model $\omega_{n}[\mathrm{~Hz}]$ (FE solution) } \\
\hline- & - & - & 13877 & 19877 & 23744 & 26896 & 29690 & 32268 & 34704 \\
\hline
\end{tabular}

In the Figs. 3 and 4 four normal modes come from the FE model are shown. 

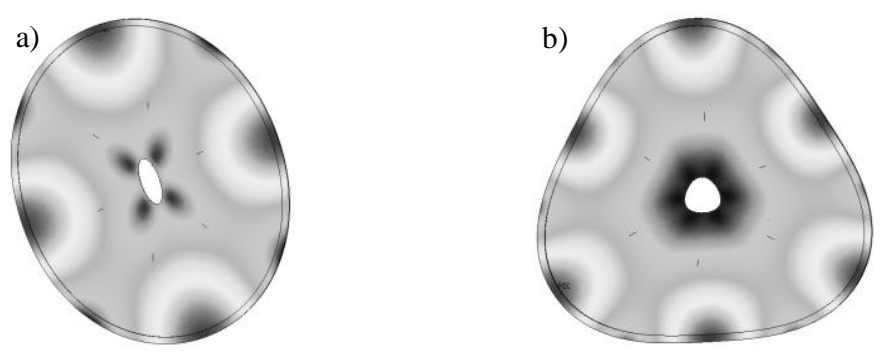

Fig. 3. Mode shapes related to the following frequencies: (a) $\omega_{2}$, (b) $\omega_{3}$

Rys. 3. Postacie drgań własnych odpowiadające częstościom (a) $\omega_{2}$, (b) $\omega_{3}$
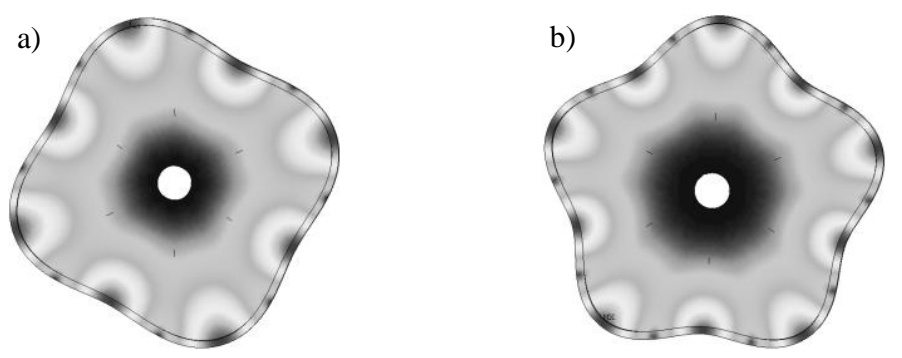

Fig. 4. Mode shapes related to the following frequencies: (a) $\omega_{4}$, (b) $\omega_{5}$

Rys. 4. Postacie drgań własnych odpowiadające częstościom (a) $\omega_{4}$, (b) $\omega_{5}$

\section{Experimental investigation}

In this section the results related to the experimental verification of the considered analytical and numerical models of the system under study are discussed. LMS measurement set is employed in the experimental investigation. The measuring set consisted of the PCB model 086C03 type modal hammer equipped with a gauging point made of steel, accelerometer PCB model 353B18, LMS SCADA data acquisition system, and SCM-V4E type measuring module supported by LMS Test.Lab software. The experimental investigation is conducted to identify natural frequencies and corresponding normal modes related to the in-plane flexural vibration of the object under study. The values of the excited natural frequencies are displayed in Table 3 . These values are compared with the values of natural frequencies from the FE and analytical model, respectively. In the same Table the values of the frequency error related to the discussed models are included. The achieved results are satisfactory and a better fit is obtained for the analytical model (especially for the frequency $\omega_{7}$, see Table 3). 
Table 3. Results of verification of the system under study

Tabela 3. Wyniki badań doświadczalnych rozważanego układu

\begin{tabular}{|l|c|c|c|c|c|c|c|}
\hline $\boldsymbol{n}$ & $\mathbf{2}$ & $\mathbf{3}$ & $\mathbf{4}$ & $\mathbf{5}$ & $\mathbf{6}$ & $\mathbf{7}$ & $\mathbf{8}$ \\
\hline & & & & & \\
\hline \\
\hline
\end{tabular}

In the Figs. 5 and 6 four normal modes come from the experimental test are shown.
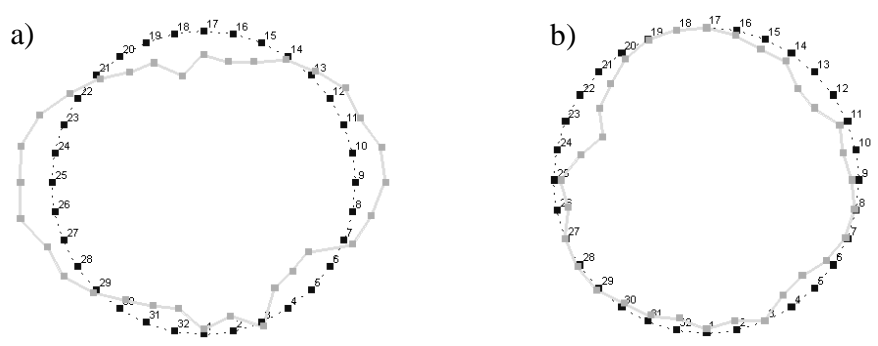

Fig. 5. Mode shapes related to the following frequencies: (a) $\omega_{2}$, (b) $\omega_{3}$ Rys. 5. Postacie drgań własnych odpowiadające częstościom (a) $\omega_{2}$, (b) $\omega_{3}$
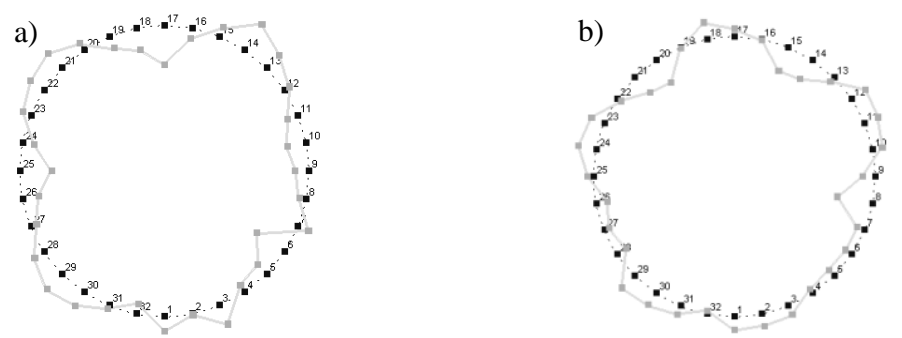

Fig. 6. Mode shapes related to the following frequencies: (a) $\omega_{4}$, (b) $\omega_{5}$

Rys. 6. Postacie drgań własnych odpowiadające częstościom (a) $\omega_{4}$, (b) $\omega_{5}$

\section{Conclusions}

In this paper, a comprehensive study of the free in-plane flexural vibration analysis of thin ring with wheel-plate as a special three-parameter Winkler foundation is investigated on basis of the analytical method and numerical simu- 
lation. The separation of variables method is employed to solve the free vibration problem. The obtained analytical and numerical solutions are verified successfully during experimental investigation.

\section{Literatura}

[1] Bert C.W., Chen T.L.C.: On vibration of a thick flexible ring rotating at high speed, Journal of Sound and Vibration, 61, 1978, pp. 517-530.

[2] Noga S., Bogacz R., Markowski T.: Vibration analysis of wheels composed of a ring and wheel-plate modeled as the three-parameters elastic foundation, Journal of Sound and Vibration, 2014, http://dx.doi.org/10.1016/j.jsv.2014.07.019.

[3] Noga S., Markowski T., Bogacz R.: Natural frequencies of flexural vibration of a ring with wheel-plate as the Winkler elastic foundation, Symulacja w Badaniach i Rozwoju, vol. 3, no. 1, 2012, pp. 39-46.

[4] Noga S., Markowski T.: In plane flexural vibration of a ring interacting with the Winkler foundation, Vibration in Physical System, vol. XXV, 2012, pp. 305-310.

[5] Rao S.S.: Vibration of Continuous Systems, Wiley, Hoboken, 2007.

[6] Wu X., Parker R.G.: Vibration of rings on a general elastic foundation, Journal of Sound and Vibration, 295, 2006, pp. 194-213.

\section{ANALIZA DRGAŃ CIENKIEGO PIERŚCIENIA WSPÓLPRACUJĄCEGO Z PLYTĄ PIERŚCIENIOWĄ, TRAKTOWANĄ JAKO PODLOŻE SPRĘŻYSTE}

\section{Streszczenie}

W pracy analizowane są drgania giętne w płaszczyźnie cienkiego pierścienia współpracującego z podłożem sprężystym typu Winklera, w oparciu o metody analityczne i numeryczne. Zaproponowano trzyparametryczny model matematyczny podłoża sprężystego. Zagadnienie drgań własnych układu rozwiązano metodą rozdzielenia zmiennych. Następnie wykorzystując metodę elementów skończonych, rozwiązano zagadnienie własne omawianego układu. Otrzymane rozwiązania zweryfikowano badaniami doświadczalnymi. Wymagane modele MES opracowano w środowisku obliczeniowym ANSYS. Warto podkreślić, że omawiane w pracy zagadnienia mogą być pomocne inżynierom, zajmującym się obliczeniami dynamiki układów kołowych (kół zębatych, kół kolejowych).

Słowa kluczowe: drgania giętne w płaszczyźnie, pierścień z podłożem sprężystym, trzyparametryczne podłoże sprężyste, układy kołowe

DOI:10.7862/rb.2014.35

Przesłano do redakcji: 13.05.2014 r.

Przyjęto do druku: 04.09.2014 r. 